\title{
MicroRNA-19a mediates gastric carcinoma cell proliferation through the activation of nuclear factor- $\mathrm{k} B$
}

\author{
FAN YANG ${ }^{1,2 *}$, HONGJIAN WANG ${ }^{2 *}$, ZHENYU JIANG $^{2}$, ANXIANG HU $^{2}$, \\ LISHA CHU ${ }^{2}$, YILING SUN ${ }^{2}$ and JUNQING HAN ${ }^{1}$
}

\begin{abstract}
${ }^{1}$ Department of Tumor Research and Therapy Center, Provincial Hospital Affiliated to Shandong University, Jinan, Shandong 250021; ${ }^{2}$ Department of Oncology, Tengzhou Central People's Hospital, Tengzhou, Shandong 277500, P.R. China
\end{abstract}

Received September 27, 2014; Accepted June 22, 2015

DOI: $10.3892 / \mathrm{mmr} .2015 .4151$

\begin{abstract}
In gastric carcinoma, the nuclear factor- $\kappa \mathrm{B}(\mathrm{NF}-\kappa \mathrm{B})$ signaling pathway is highly active, and the constitutive activation of NF- $\mathrm{NB}$ prompts malignant cell proliferation. MicroRNAs are considered to be important mediators in the regulation of the $N F-\kappa B$ signaling pathway. The present study predominantly focussed on the effects of microRNA (miR)-19a on NF- $\kappa \mathrm{B}$ activation. Reverse transcription-quantitative polymerase chain reaction was used to quantify the relative levels of miR-19a in gastric carcinoma cells. MTT assays were used to determine the effect of miR-19a on cellular proliferation. To detect the activation of $\mathrm{NF}-\kappa \mathrm{B}$, western blotting was performed to measure the protein levels of $\mathrm{NF}-\kappa \mathrm{B}$ and the products of its downstream target genes. To define the target genes, luciferase reporter assays were used. miR-19a was found to be markedly upregulated in gastric carcinoma cells. The overexpression of miR-19a resulted in proliferation and enhanced migratory capabilities of the MGC-803 gastric carcinoma cell line. The results of the western blot analysis demonstrated that the protein levels of p65 increased when the MGC-803 cells were transfected with miR-19a mimics. In addition, the downstream target genes of miR-19a, including intercellular adhesion molecule, vascular cell adhesion molecule and monocyte chemoattractant protein-1, were upregulated. The results of the luciferase assay indicated that $\mathrm{I} \kappa \mathrm{B}-\alpha$ was the target gene of miR-19a. Therefore, the results of the present study suggested that miR-19a enhances malignant gastric cell proliferation by constitutively activating the NF- $\mathrm{NB}$ signaling pathway.
\end{abstract}

Correspondence to: Dr Junqing Han, Department of Tumor Research and Therapy Center, Provincial Hospital Affiliated to Shandong University, 324 Jingwuweiqi Road, Jinan, Shandong 250021, P.R. China

E-mail: fanyang0727@163.com

*Contributed equally

Key words: microRNA-19a, gastric carcinoma cell, nuclear factor- $\kappa \mathrm{B}$ activation

\section{Introduction}

Gastric cancer is one of the most common types of malignant tumor in China (1). At present, the rate of gastric cancer-associated mortality is increasing, accounting for almost a quarter of the total cases of cancer-associated mortality worldwide (2). In addition, the number of patients diagnosed with gastric cancer has increased $(2,3)$. Thus, it is clear that gastric cancer presents a serious threat to public health. Gastric cancer can occur at any age, with the majority of patients diagnosed between the ages of 40 and 60 years (3). At present, no single cause has been identified; however, associated factors have been reported to include diet, lifestyle, environmental factors, genetic predisposition and Helicobacter pylori infection (4). At present, comprehensive therapy, including chemotherapy, is the main method for the treatment method used for treating advanced gastric cancer (5). Chemotherapeutic drugs do not only cause tumor cell death, they also damage normal tissue cells, therefore, the overall survival rate of patients with gastric cancer is not significantly improved by chemotherapy alone (6). Thus, in order to maximize the effect of eradicating tumor cells in malignant tumor tissues, greater importance has been placed upon the identification of pharmaceutical drugs exhibiting the lowest toxicity towards normal cells (7).

The nuclear factor- $\kappa \mathrm{B}(\mathrm{NF}-\kappa \mathrm{B})$ transcriptional factor family consists of five subunits: Rel (cRel), p65 (RelA;

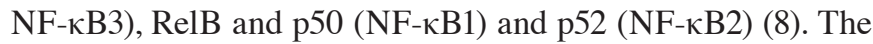
two most common dimers of $\mathrm{NF}-\kappa \mathrm{B}$ include p65 and p50. In resting cells, I $\mathrm{B}$, the inhibitory unit of $\mathrm{NF}-\kappa \mathrm{B}$, combines with $\mathrm{NF}-\kappa \mathrm{B}$, resulting in inactivation of the cytoplasmic form. When the cells are stimulated by extracellular signals, the I $\kappa \mathrm{B}$ kinase

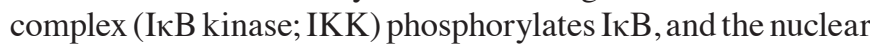
localization sites of $\mathrm{NF}-\kappa \mathrm{B}$ are exposed. Subsequently, the free $N F-\kappa B$ rapidly translocates into the nucleus and combines with specific $\kappa B$ sequences that induce gene transcription (9). Previous histological studies have indicated the importance of local inflammation in nasopharyngeal carcinoma tumorigenesis (10). As a key inflammatory signaling pathway, $\mathrm{NF}-\kappa \mathrm{B}$ has been demonstrated to be constitutively active in tumors by immunohistochemical staining (10). The constitutive activation of NF- $\mathrm{NB}$ commonly results in malignant carcinoma cell proliferation in various cancer cells and tissues, due to the fact 
that the NF- $\mathrm{NB}$ signaling pathway regulates a series of target genes involved in cellular proliferation, apoptosis, immune response and transcription $(11,12)$.

MicroRNAs (miRNAs) are small, non-coding RNAs of 20-25 nucleotides in length. miRNAs negatively regulate gene expression via incomplete complementarity to the 3'-untranslated regions (UTR) of the target genes (13). In previous years, the aberrant expression of miRNAs has been increasingly linked with various types of human cancer (14). In addition, as important mediators, miRNAs are known to be key modulators or effectors of the NF- $\kappa \mathrm{B}$ signaling pathway (15). For example, miR-146a and miR-146b negatively interact with interleukin-1 receptor-associated kinase 1 and tumor necrosis factor (TNF) receptor-associated factor 6 protein levels, resulting in the activation of $\mathrm{NF}-\kappa \mathrm{B}$ (16). In addition, miR-199a has been demonstrated to suppress IKK $\beta$, which reduces the activity of $\mathrm{NF}-\kappa \mathrm{B}$ signaling (17).

The present study aimed to investigate the relative expression levels of miR-19a in human gastric carcinoma. The effects of increased miR-19a levels on gastric carcinoma cell proliferation and migration were also examined. These investigations aimed to determine whether miR-19a affected gastric cell proliferation and migration through the $\mathrm{NF}-\kappa \mathrm{B}$ signaling pathway, thereby preventing gastric cancer progression.

\section{Materials and methods}

Cell culture and treatments. The GES-1, MGC-803, BGC-823 and SGC-7901 human gastric carcinoma cell lines as well as HEK293T cells were purchased from American Type Culture Collection (Manassas, VA, USA) and were cultured in Dulbecco's modified Eagle's medium (DMEM)/F12 (GE Healthcare Life Sciences, Logan, UT, USA) supplemented with $10 \%$ fetal bovine serum (FBS; GE Healthcare Life Sciences), $100 \mathrm{U} / \mathrm{ml}$ penicillin and streptomycin (Invitrogen Life Technologies, Carlsbad, CA, USA) in a $25 \mathrm{~cm}^{2}$ culture flask at $37^{\circ} \mathrm{C}$ in a humidified atmosphere of $5 \% \mathrm{CO}_{2}$. Cells were treated with $10 \mathrm{ng} / \mu \mathrm{l} \mathrm{TNF}-\alpha$ for $48 \mathrm{~h}$ at $60 \%$ confluence.

Transient transfections. Prior to transfection, $1.5 \times 10^{5}$ cells/well were seeded into a 6 -well plate in $2 \mathrm{ml}$ DMEM culture medium containing FBS and antibiotics. Prior to transfection, the cells were incubated under normal growth conditions $\left(37^{\circ} \mathrm{C}\right.$ and $5 \% \mathrm{CO}_{2}$ ). Subsequently, the cells were transfected with miR-19a mimics, miR-19a inhibitors or miR negative controls for 48 h (Shanghai GenePharma Co., Ltd., Shanghai, China), which were pre-incubated with HiPerFect transfection reagent (Qiagen, Hilden, Germany), with a final concentration of miRNA analogues at $100 \mathrm{nmol} / \mathrm{l}$.

RNA extraction. Total RNA was extracted from the cell lines (5 mg) using TRIzol reagent (Invitrogen Life Technologies), according to the manufacturer's instructions.

Bioinformatic analysis. TargetScan (http://www.targetscan. org/) was used to predict the target gene of miR-19a.

Reverse transcription-quantitative polymerase chain reaction $(R T-q P C R)$. In order to detect and quantify mature microRNA-19a, a TaqMan MicroRNA Reverse Transcription kit and TaqMan MicroRNA assay were used, according to the manufacturer's instructions (Applied Biosystems, Life Technologies, Foster City, CA, USA). U6 RNA was used for normalization. To quantify the miRNA levels, $10 \mathrm{ng}$ total RNA was reverse-transcribed using the Taq-Man MicroRNA Reverse Transcription kit, using specific primers for miR-19a and U6. Nucleotide primers used for reverse transcription were as follows (5'-3'): miR-19a, GTCGTATCCAGTGCA GGGTCCGAGGTATTCGCACTGGATACGACAGAGCA; U6, GTCGTATCCAGTGCAGGGTCCGAGGTATTCGCA CTGGATACGACAAATATG. The primers used for real-time PCR were as follows (5'-3'): miR-291b-3p forward, GGCAAA CAGCAAAAC; U6 forward, GCGCGTCGTGAAGCGTTC; Universal reverse primer, GTGCAGGGTCCGAGGT. Subsequently, PCR amplifications were performed in $20 \mu \mathrm{l}$ reaction volumes, containing $10 \mu \mathrm{g}$ TaqMan $2 \mathrm{X}$ Universal PCR Master Mix, $1 \mu 1$ 20X TaqMan MicroRNA Assay mix (Applied Biosystems, Life Technologies) and $1.33 \mu$ l template cDNA in the same system used for mRNA quantitation (ABI 2720; Applied Biosystems). The thermal cycling conditions were as follows: $95^{\circ} \mathrm{C}$ for $10 \mathrm{~min}$, followed by 40 cycles at $95^{\circ} \mathrm{C}$ for $15 \mathrm{sec}$ and at $60^{\circ} \mathrm{C}$ for $1 \mathrm{~min}$. The relative miRNA expression of miR-19a was normalized against the U6 RNA endogenous control using the $2^{\triangle \Delta C T}$ method. Bio-Rad CFX Manager software (v 1.6; Bio-Rad Laboratories, Inc., Hercules, CA, USA) was used for the quantitative analysis of mRNA and miRNA.

Protein extraction, western blotting and antibody incubation. The cellular proteins were extracted from the cells using radioimmunoprecipitation buffer, containing $50 \mathrm{mM}$ Tris/ $\mathrm{HCl}$ (pH 7.4), $150 \mathrm{mM} \mathrm{NaCl}$ and $1 \%$ (v/v) NP-40, and 0.1\% (w/v) SDS (Beijing SolarBio Science \& Technology Co., Ltd., Beijing, China), containing $1 \%$ (v/v) phenylmethanesulfonylfluoride (Beijing SolarBio Science \& Technology Co., Ltd.), $0.3 \%$ (v/v) protease inhibitor (Sigma-Aldrich, St. Louis, MO, USA) and $0.1 \%$ (v/v) phosphorylated proteinase inhibitor (Sigma-Aldrich). The lysates were centrifuged at $13,000 \mathrm{xg}$ at $4^{\circ} \mathrm{C}$ for $15 \mathrm{~min}$ and the supernatant was collected for total protein analysis. A bicinchoninic protein assay kit (Pierce Biotechnology, Inc., Rockford, IL, USA) was used to determine the protein concentration. Equal quantities of protein $(15 \mu \mathrm{g})$ were separated on an SDS-PAGE gel (10\% (v/v) polyacrylamide) and transferred onto a polyvinylidene difluoride membrane (EMD Millipore, Billerica, MA, USA). Nonspecific binding was blocked using $8 \%(\mathrm{w} / \mathrm{v})$ milk in Tris-buffered saline with 1\% Tween-20 (TBST; Beijing SolarBio Science \& Technology Co., Ltd.) for $2 \mathrm{~h}$ at room temperature. The membranes were then incubated with primary antibodies against $\beta$-actin (13E5) rabbit monoclonal antibody (mAb) (cat no. 4970; Cell Signaling Technology Inc., Beverly, MA, USA), NF-кB p65 (L8F6) mouse mAb (cat no. 6956; Cell Signaling Technology), NF-кB p65 (D14E12) XP ${ }^{\circledR}$ rabbit mAb \#9609 (Cell Signaling Technology Inc.); VCAM-1 (E1E8X) rabbit mAb \#13662 (Cell Signaling Technology Inc.) ICAM-1 rabbit mAb \#4915 (Cell Signaling Technology Inc.); MCP-1 rabbit mAb \#2027 (Cell Signaling Technology Inc.) overnight at $4^{\circ} \mathrm{C}$. Following several washes with TBST, the membranes were incubated in horseradish peroxidase (HRP)-conjugated goat anti-rabbit and anti-mouse immunoglobulin (Ig)G or HRP-conjugated 
mouse anti-goat IgG (all at a 1:5,000 dilution) for $2 \mathrm{~h}$ at room temperature and were then washed (five times with TBST for $10 \mathrm{~min}$ each). The target proteins were visualized using enhanced chemiluminescence (EMD Millipore), according to the manufacturer's instructions, and were quantified using density analysis normalized against $\beta$-actin, according to the manufacturer's instructions, with values expressed as the fold-changes, compared with the control.

Inhibition of $N F-\kappa B$ by RNA interference. NF- $\mathrm{KB}$-specific small interfering (si)RNA (siHuR) and negative control were purchased from Shanghai Genepharma. $1 \times 10^{5}$ cells per well in a six-well plate were transfected with $50 \mathrm{nM}$ siHuR or negative control for $48 \mathrm{~h}$ using HiperFect transfection reagent (Qiagen) as described above.

Luciferase target assay. For the luciferase assay, the 3' UTR of I $\mathrm{B} \alpha$, including the binding site for miR-19a, was amplified from the MGC-803 cells using the following primers: I $\kappa \mathrm{B} \alpha$, forward 5'-AAGGAGGAGGGCAGAATCAT-3' and reverse, 5'-ATCTGCATGGTGATGTTGGA-3'. The PCR product was then digested with XbaI (New England Biolabs, Beverly, MA, USA) and cloned into the pGL3 reporter plasmid (Promega Corporation, Madison, WI, USA), downstream of the luciferase reporter gene.

The modified firefly luciferase vector $(500 \mathrm{ng} / \mu \mathrm{l})$ was transfected into HEK293 cells $\left(2 \times 10^{5}\right.$ cells $\left./ \mathrm{ml}\right)$, as described previously, and firefly and Renilla luciferase activities were measured $48 \mathrm{~h}$ after transfection using a Dual-Luciferase Reporter Assay system (Promega Corporation). Firefly activity was normalized to Renilla activity to control the transfection efficiency.

Immunofluorescence. MGC-803 cells were cultured on six-well chamber slides and fixed with $4 \%$ paraformaldehyde for $10 \mathrm{~min}$ at $-20^{\circ} \mathrm{C}$. The slides were washed in PBS three times and incubated with a polyclonal antibody against NF- $\mathrm{\kappa B}$ (1:50 diluted in PBS with $1 \% \mathrm{BSA} ; 50 \mu \mathrm{l} / \mathrm{slide}$ ) for $2 \mathrm{~h}$ at room temperature. After washing with PBS three times (5 min per time), the slides were incubated with tetramethylrhodamine-conjugated anti-rabbit IgG (Beijing Zhongshan Jinqiao Biotechnology Co., Ltd, Beijing, China; diluted 1:100 in PBS with $1 \% \mathrm{BSA} ; 50 \mu \mathrm{l} /$ slide) for $1 \mathrm{~h}$ at room temperature. Three times after washing the slides in PBS, the slides were incubated with Hoechst $33258(10 \mu \mathrm{g} / \mathrm{ml})$ for $5 \mathrm{~min}$. The slides were then washed again and examined using a fluorescence microscope (Leica CM3000; Leica Microsystems GmbH, Buffalo Grove, IL, USA).

MTT assay. In order to evaluate the effect of miR-19a on cell proliferation, the cells were seeded at 5,000 cells/well in $100 \mu \mathrm{l}$ medium in 96-well plates and were transfected with miR-19a mimics or inhibitors $(50 \mathrm{nM})$ or negative control-miRNA mimics $(50 \mathrm{nM})$, as described above. Following transfection, $20 \mu 1$ MTT reagent (Beijing SolarBio Science \& Technology Co., Ltd.) was added to the wells after $24 \mathrm{~h}$ and incubated for $4 \mathrm{~h}$ at $37^{\circ} \mathrm{C}$. Subsequent to removal of the medium, $200 \mu 1$ dimethyl sulfoxide was added to dissolve the formazan, and the absorbance was measured at $550 \mathrm{~nm}$ using a SpectraMax ${ }^{\circledR}$ M3 (Molecular Devices Inc., Sunnyvale, CA,

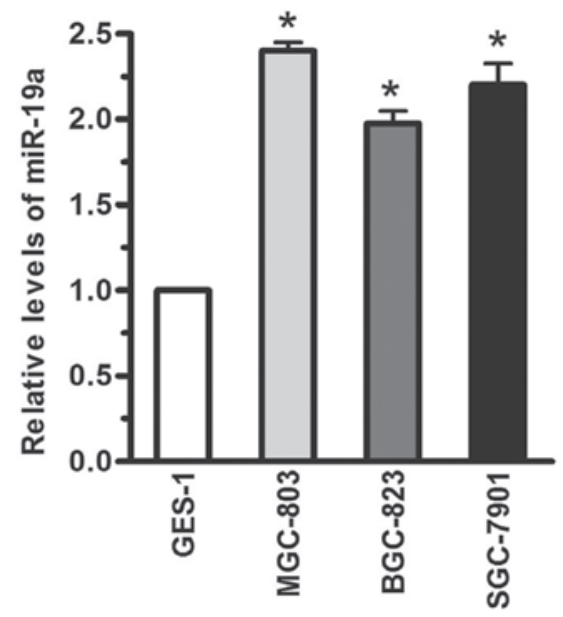

Figure 1. Expression levels of miR-19a in human gastric carcinoma cells Reverse transcription-quantitative polymerase chain reaction analysis of the expression of miR-19a in the MGC-803, BGC-823 and SGC-7901 human gastric carcinoma cell lines and in the immortalized GES-1 gastric epithelial cell line. RNU48 was used as an endogenous control. Data are presented as the mean \pm standard error of three independent experiments ${ }^{*} \mathrm{P}<0.05$, vs. control. miR, microRNA.

USA). Wells containing only MGC-803 cells served as blank controls.

Statistical analysis. Data are presented as the mean \pm standard error of three independent experiments. ImageJ software (National Institutes of Health, Bethesda, MD, USA) was used for density analysis. GraphPad Prism (GraphPad, Inc., La Jolla, CA, USA) was used for statistical analyses. Student's $\mathrm{t}$-test was used to assess differences between groups. $\mathrm{P}<0.05$ was considered to indicate a statistically significant difference.

\section{Results}

miR-19a is upregulated in human gastric carcinoma cells. The relative levels of miR-19a in human gastric carcinoma cells were detected using RT-qPCR. Compared with the GES-1 immortalized gastric epithelial cell line, the miR-19a levels were significantly increased ( $>1$-fold) in the MGC-803, BGC-823 and SGC-7901 human gastric carcinoma cell lines, when the miR-19a expression level was normalized to U6 (Fig. 1; P<.05). Based on these results, the levels of miR-19a were significantly increased in human gastric carcinoma cells.

Upregulation of miR-19a increases MGC-803 cell viability. To investigate the effect of miR-19a on MGC-803 cell viability, the MGC-803 cells were transfected with miR-19a mimics, inhibitors or negative controls for 24,48 or $72 \mathrm{~h}$, respectively. In this investigation, the mimics were analogues that enhanced the expression of miR-19a, whereas the inhibitors were analogues that reduced the expression of miR-19a. The MTT assay demonstrated that, when the miR-19a mimics were transfected into the MGC-803 human gastric carcinoma cell line, cell viability was significantly increased by 23 and $35 \%$ at 48 and 72 h, respectively (Fig. 2A). Conversely, when the expression of miR-19a was inhibited, cell viability was 
A

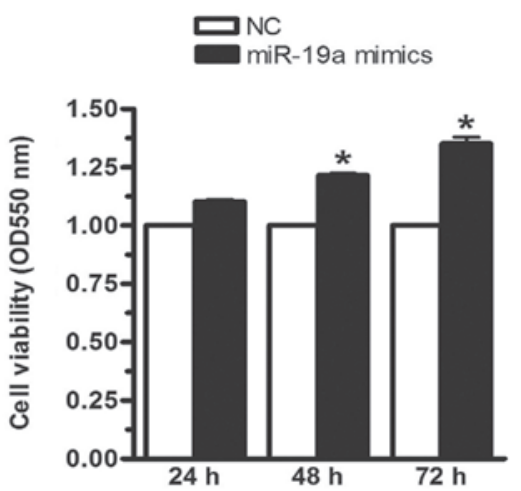

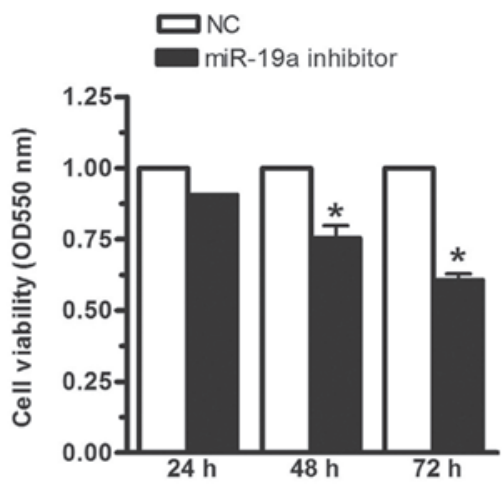

Figure 2. Cell viability of the MGC-803 human gastric carcinoma cell line is increased by miR-19a. The MGC-803 cells were transfected with (A) miR-19a mimics or (B) miR-19a inhibitors and negative controls for 24,48 or $72 \mathrm{~h}$, respectively. The relative expression level of miR-19a was determined using reverse transcription-quantitative polymerase chain reaction and RNU48 was used an internal control. Cell viability was determined using an MTT assay. Data are presented as the mean \pm standard error of three independent experiments. ${ }^{*} \mathrm{P}<0.05$, vs. control. miR, microRNA; OD, optical density; NC, negative control.

A

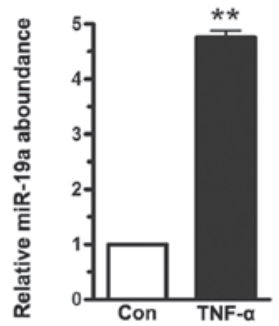

B
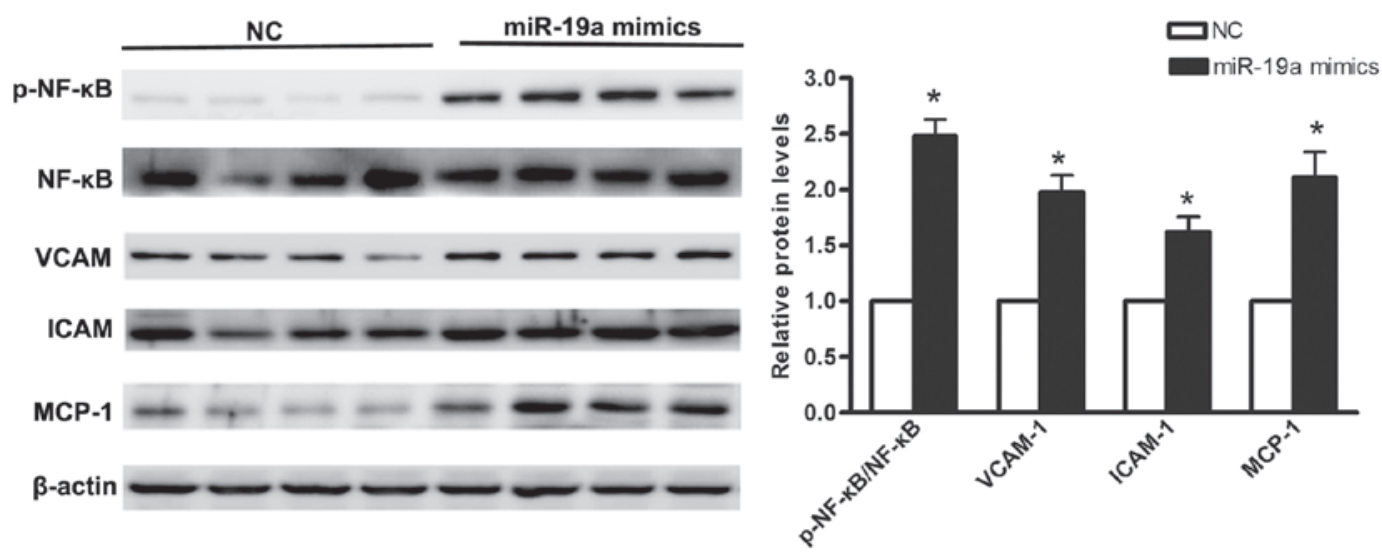

C

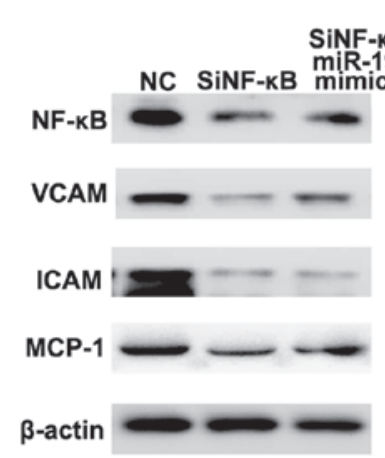

D

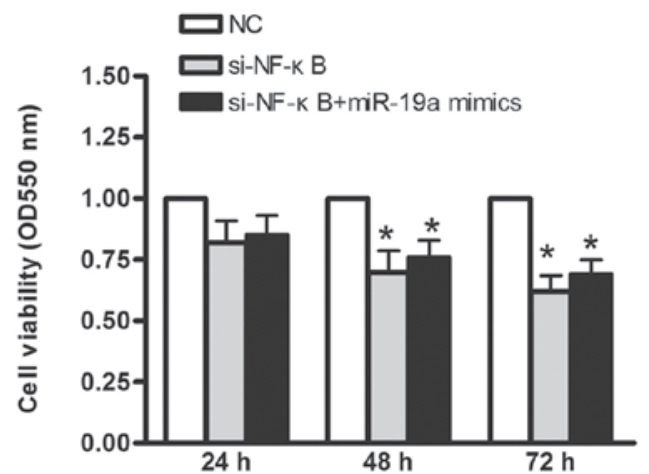

Figure 3. NF- $\mathrm{kB}$ signaling pathway is activated when miR-19a is overexpressed in the MGC-803 human gastric carcinoma cell line. (A) Reverse transcription-quantitative polymerase chain reaction was used to determine the relative levels of miR-19a when MGC- 803 cells were treated with $10 \mathrm{ng} / \mu 1 \mathrm{TNF}-\alpha$ for $48 \mathrm{~h}$. (B) Western blot analysis of NF-kB activation and its downstream regulators when miR-19a was overexpressed. (C) Western blot analysis of siRNA

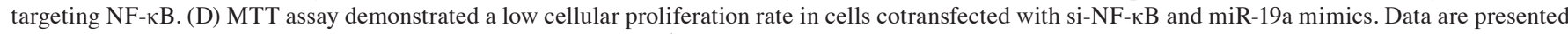
as the mean \pm standard error of three independent experiments. " $\mathrm{P}<0.05$, vs. control. TNF- $\alpha$, tumor necrosis factor- $\alpha$; NF- $\mathrm{\kappa B}$, nuclear factor- $\mathrm{kB}$; VCAM, vascular cell adhesion molecule; ICAM, intercellular adhesion molecule; MCP, monocyte chemoattractant protein; miR, microRNA; si, small interfering; p-, phosphorylated; NC, negative control; Con, control. 
A

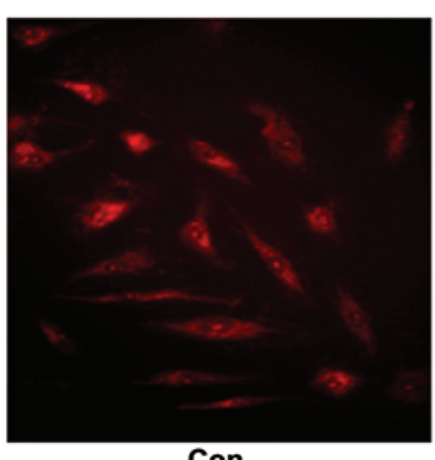

Con

B
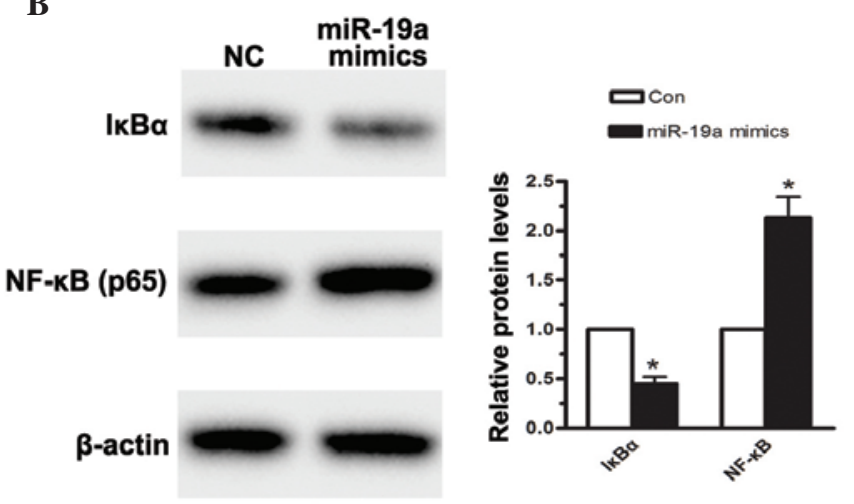

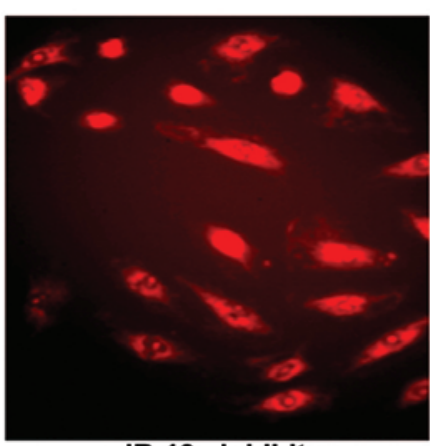

miR-19a inhibitor

C

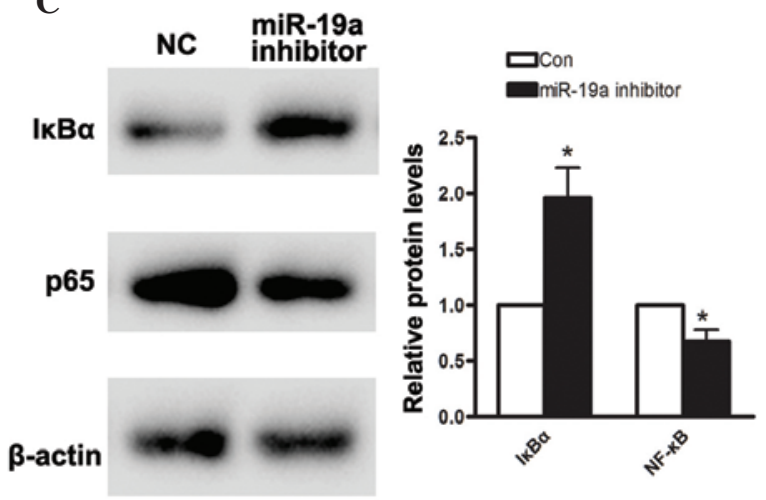

D

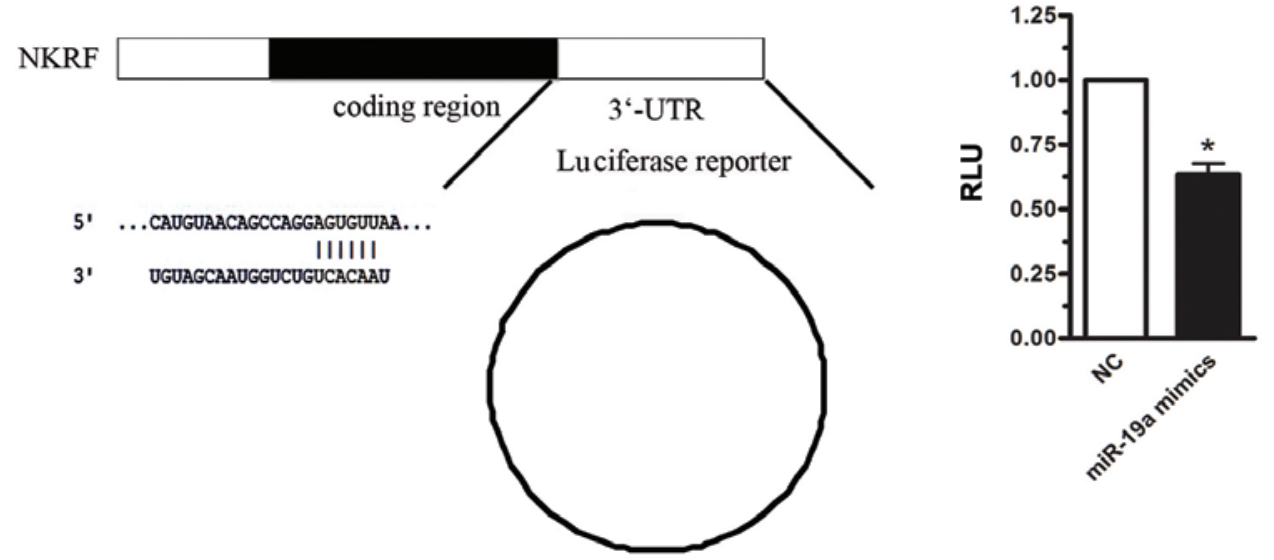

Figure 4. miR-19a targets I $\mathrm{B} \alpha$ in MGC-803 human gastric carcinoma cells. (A) Immunofluorescence analysis of the expression of NF- $\kappa \mathrm{B}$ when MGC-803 cells were transfected with miR-19a or negative control (magnification, x100). Western blot analysis of I $\kappa$ B $\alpha$ was performed on the MGC-803 cells transfected with (B) miR-19a mimics or (C) miR-19a inhibitors and negative controls. (D) Luciferase reporter assay to detect the effect of miR-19a on IкB $\alpha-3$ '-UTR. Data are presented as the mean \pm standard error of three independent experiments. ${ }^{*} \mathrm{P}<0.05$, vs. control. NF- $\kappa \mathrm{B}$, nuclear factor- $\kappa \mathrm{B}$; miR, microRNA; NFKR, $\mathrm{NF}-\kappa \mathrm{B}$-repressing factor; UTR, untranslated region; NC, negative control; Con, control.

reduced by 17 and $36 \%$ at 48 and $72 \mathrm{~h}$, respectively (Fig. 2B). These results indicated that miR-19a increased MGC-803 cell viability.

miR-19a activates the $N F-\kappa B$ signaling pathway. In gastric carcinoma, the NF- $\kappa \mathrm{B}$ signaling pathway is constitutively activated. In previous studies, several miRNAs have been reported to activate NF- $\kappa$ B. For example, miR-301a has been demonstrated to target NF- $\mathrm{KB}$-repressing factor and to correlate with abnormal NF- $\mathrm{BB}$ activation (17). In the present study, the MGC-803 gastric carcinoma cells were treated with $10 \mathrm{ng} / \mu \mathrm{l}$ TNF- $\alpha$ for $48 \mathrm{~h}$, following which the relative levels of miR-19a were analyzed. As shown in Fig. 3A, the relative levels of miR-19a increased $\sim 4$-fold following TNF- $\alpha$ treatment. In addition, western blotting was performed to ascertain whether TNF- $\alpha$ treatment significantly activated the NF- $\kappa B$ signaling pathway. To address whether miR-19a contributes to NF- $\mathrm{KB}$ activation, the MGC-803 gastric 
carcinoma cells were transfected with miR-19a mimics. Based on the results of the western blot analysis, it was concluded that when miR-19a was overexpressed, NF- $\kappa \mathrm{B}$ was significantly activated. As shown in Fig. 3A, compared with the negative control, the phosphorylated-NF- $\mathrm{B} / \mathrm{NF}-\kappa \mathrm{B}$ ratio was increased by $>1$-fold. Vascular cell adhesion molecule (VCAM), intercellular adhesion molecule (ICAM) and monocyte chemoattractant protein-1 (MCP-1) are among the important adhesion molecules that are aberrantly expressed in various types of cancer (18). To validate the abnormal NF- $\kappa \mathrm{B}$ activation, the protein levels of VCAM, ICAM and MCP-1 were measured. As shown in Fig. 3B, their relative levels were all increased $\sim 1$-fold. Based on the above results, it was concluded that miR-19a contributed to TNF- $\alpha$-stimulated $N F-\kappa B$ activation. In order to investigate the effect of $N F-\kappa B$ on cellular proliferation, a small interfering (si)RNA-targeting $\mathrm{NF}-\kappa \mathrm{B}$ was selected. As shown in Fig. 3C, following knockdown of NF- $\kappa \mathrm{B}$, cell viability was significantly reduced, even in the cells transfected with the miR-19a mimics. The MTT assay demonstrated that cell viability was significantly reduced in the cells transfected with si-NF-кB. These data suggested that miR-19a enhanced cellular proliferation through activation of the $N F-\kappa B$ signaling pathway.

$I \kappa B \alpha$ is the host gene of miR-19a. To further confirm that $\mathrm{NF}-\kappa \mathrm{B}$ was activated upon miR-19a overexpression, immunofluorescence was measured. As shown in Fig. 4A, enhanced $\mathrm{NF}-\kappa \mathrm{B}$ (p65) protein levels were detected when the MGC-803 cells were transfected with miR-19a mimics. According to TargetScan, miR-19a was predicted to target $\mathrm{I} \kappa \mathrm{B} \alpha$. I $\mathrm{B}$ is an $\mathrm{NF}-\kappa \mathrm{B}$ inhibitory protein (19). In the resting state, $\mathrm{I} \kappa \mathrm{B}-\alpha$ combines with p65, P50, resulting in the inactivation of $\mathrm{NF}-\kappa \mathrm{B}$ in the cytoplasm. Through the activation of IKK, I $\kappa \mathrm{B} \alpha$ is degraded, which drives the two subunits of NF- $\mathrm{NB}$ to translocate between the cytoplasm and the nucleus, particularly the p65 subunit, inducing a downstream signaling pathway. Therefore, the effects of miR-19a on the expression of $\mathrm{I} \kappa \mathrm{B} \alpha$ were assessed. When the MGC-803 human gastric carcinoma cell line was transfected with miR-19a mimics for $48 \mathrm{~h}$, the density of I $\kappa \mathrm{B} \alpha$ was significantly reduced, compared with the negative control (Fig. 4B). Furthermore, $48 \mathrm{~h}$ following transfection of the MGC-803 cells with miR-19a, the expression level of I $\mathrm{B} \alpha$ was reduced by $56 \%$. Conversely, when miR-19a was inhibited in the MGC-803 cells, the expression level of I $\mathrm{B} \alpha$ was increased by almost 1-fold (Fig. 4C). A luciferase assay was also performed to detect the effect of miR-19a on the 3'-UTR region of $\mathrm{I} \kappa \mathrm{B} \alpha$. As shown in Fig. 4D, miR-19a significantly reduced $\mathrm{I} \kappa \mathrm{B} \alpha-3$ '-UTR-luciferase reporter activity. Based on the above analysis, it was suggested that miR-19a induced $\mathrm{NF}-\kappa \mathrm{B}$ activation, predominantly by targeting $\mathrm{I} \kappa \mathrm{B} \alpha$, in the human gastric carcinoma cells.

\section{Discussion}

miRNAs have been widely demonstrated to regulate various cellular processes, particularly during cancer development and progression (20). Gastric carcinoma is common in males and females, and substantial efforts being made to identify their metastatic characteristics. Several previous studies have indicated abnormal miRNA levels in gastric carcinoma $(21,22)$, and the present study demonstrated that miR-19a was abnormally upregulated in MGC-803 human gastric carcinoma cells (23). This result suggests an oncogenic role for miR-19a in the progression of gastric carcinoma. The MGC- 803 cell is an immortal cell line, derived from human gastric carcinoma, which has been widely applied in the investigation of gastric cancer. In the present study, the BGC-823 and SGC-7901 human gastric cancer cell lines were also investigated. In the present study, the MGC-803, BGC-823 and SGC-7901 cells were first treated with miR-19a inhibitors. According to the MTT assay, the inhibition of cell proliferation demonstrated that tumor growth was significantly inhibited.

To analyze the correlation between miR-19a and human gastric carcinoma, the relative levels of miR-19a were assessed in human gastric carcinoma cells. The results demonstrated that miR-19a was upregulated. In addition, miR-19a was found to activate MGC-803 cell proliferation in the MTT assay. The data obtained in the present study indicated that TNF- $\alpha$ treatment induced miR-19a overexpression by $\sim 4$-fold in the MGC-803 human gastric carcinoma cells. Notably, NF- $\kappa$ B was activated when the MGC- 803 cells were transfected with miR-19a mimics for $48 \mathrm{~h}$, and the downstream regulators of the NF- $\kappa \mathrm{B}$ signaling pathway, including VCAM, ICAM and MCP-1, were also upregulated. As all these molecules are particularly important for tumor metastasis, the activation of the $N F-\kappa B$ signaling pathway was further validated (24). As IKB- $\alpha$ is considered an important target gene for $N F-\kappa B$, its relative levels were assessed using western blotting and luciferase assays. These two sets of data indicated that miR-19a induced $\mathrm{NF}-\kappa \mathrm{B}$ activation by targeting $\mathrm{I} \kappa \mathrm{B} \alpha$.

Dysregulation of the $N F-\kappa B$ signaling pathway is well-characterized in cancer cell proliferation, angiogenesis, migration and invasion $(25,26)$, and the present study confirmed the abnormal activation of $\mathrm{NF}-\kappa \mathrm{B}$ in human gastric carcinoma. In order to examine the possibility that miR-19a is involved in $\mathrm{NF}-\kappa \mathrm{B}$ activation, western blot analysis of $\mathrm{NF}-\kappa \mathrm{B}$ and its downstream regulator protein levels was performed. The data suggested that the proteins examined were positively regulated by miR-19a, and that $\mathrm{I} \kappa \mathrm{B} \alpha$ was a target gene for miR-19a. I $\kappa \mathrm{B} \alpha$ is considered to repress $\mathrm{NF}-\kappa \mathrm{B}$ translation by binding to specific negative regulatory elements (27). However, the biological activity of nucleolar I $\mathrm{B} \alpha$ remains to be fully elucidated (28).

In conclusion, the present study demonstrated that miR-19a was overexpressed in human gastric carcinoma cells and that miR-19a enhances human gastric carcinoma MGC-803 cell proliferation. Furthermore, miR-19a activated the NF- $\kappa \mathrm{B}$ signaling pathway by targeting $\mathrm{I} \kappa \mathrm{B} \alpha$, a negative regulator.

\section{References}

1. Zhang W, Ha M, Gong Y, Xu Y, Dong N and Yuan Y: Allicin induces apoptosis in gastric cancer cells through activation of both extrinsic and intrinsic pathways. Oncol Rep 24: 1585-1592,2010.

2. Ha MW and Yuan Y: Allicin induced cell cycle arrest in human gastric cancer cell lines. Zhonghua Zhong Liu Za Zhi 26: 585-589, 2004 (In Chinese).

3. Park SY, Cho SJ, Kwon HC, Lee KR, Rhee DK and Pyo S: Caspase-independent cell death by allicin in human epithelial carcinoma cells: Involvement of PKA. Cancer Lett 224: 123-132, 2005. 
4. Zhang YW, Eom SY, Yim DH, Song YJ, Yun HY, Park JS, Youn SJ, Kim BS, Kim YD and Kim H: Evaluation of the relationship between dietary factors, CagA-positive Helicobacter pylori infection and RUNX3 promoter hypermethylation in gastric cancer tissue. World J Gastroenterol 19: 1778-1787, 2013

5. Lee J, Kim KM, Kang WK and Ou SH: Innovative personalized medicine in gastric cancer: time to move forward. Clin Genet 86 37-43, 2014.

6. Sato T, Kikuchi Y, Saito T, Hirano S and Kouzuma T: Results of chemotherapy using new anti-cancer drugs since S-1 for advanced or recurrent gastric cancer in our institute. Gan To Kagaku Ryoho 34: 1819-1825, 2007 (In Japanese).

7. Monjazeb AM and Blackstock AW: The impact of multimodality therapy of distal esophageal and gastroesophageal junction adenocarcinomas on treatment-related toxicity and complications. Semin Radiat Oncol 23: 60-73, 2013.

8. Burkitt MD, Williams JM, Duckworth CA, O'Hara A, Hanedi A Varro A, Caamaño JH and Pritchard DM: Signaling mediated by the NF- $\kappa \mathrm{B}$ sub-units NF- $\kappa \mathrm{B} 1, \mathrm{NF}-\kappa \mathrm{B} 2$ and c-Rel differentially regulate Helicobacter felis-induced gastric carcinogenesis in C57BL/6 mice. Oncogene 32: 5563-5573, 2013.

9. Shostak K and Chariot A: EGFR and NF- $\mathrm{kB}$ : partners in cancer. Trends Mol Med. 21: 385-393, 2015.

10. Chung GT, Lou WP, Chow C, To KF, Choy KW, Leung AW, Tong CY, Yuen JW, Ko CW, Yip TT, et al: Constitutive activation of distinct NF- $\kappa \mathrm{B}$ signals in EBV-associated nasopharyngeal carcinoma. J Pathol 231: 311-322, 2013.

11. LaBarbera KE, Hyldahl RD, O'Fallon KS, Clarkson PM and Witkowski S: Pericyte NF- $\mathrm{B}$ activation enhances endothelial cell proliferation and proangiogenic cytokine secretion in vitro. Physiol Rep 3: e12309, 2015.

12. Colangelo T, Fucci A, Votino C, Sabatino L, Pancione M, Laudanna C Binaschi M, Bigioni M, Maggi CA, Parente D, et al: MicroRNA-130b promotes tumor development and is associated with poor prognosis in colorectal cancer. Neoplasia 15: 1086-1099, 2013.

13. Jeong D, Kim J, Nam J, et al: MicroRNA-124 links p53 to the NF- $\mathrm{B}$ pathway in B-cell lymphomas. Leukemia: doi: 10.1038/leu.2015.

14. Ni F, Guo C, Sun R, et al: MicroRNA transcriptomes of distinct human NK cell populations identify miR-362-5p as an essential regulator of NK cell function. Sci Rep 5: 99932015.

15. Taganov KD, Boldin MP, Chang KJ and Baltimore D: NF-kappaB-dependent induction of microRNA miR-146, an inhibitor targeted to signaling proteins of innate immune responses. Proc Natl Acad Sci USA 103: 12481-12486, 2006.
16. Dai L, Gu L and Di W: MiR-199a attenuates endometrial stromal cell invasiveness through suppression of the IKK $\beta / N F-\kappa B$ pathway and reduced interleukin-8 expression. Mol Hum Reprod 18: 136-145, 2012.

17. Lu Z, Li Y, Takwi A, Li B, Zhang J, Conklin DJ, Young KH, Martin R and Li Y: miR-301a as an NF- $\kappa$ B activator in pancreatic cancer cells. EMBO J 30: 57-67, 2011.

18. Astarci E, Sade A, Cimen I, Savas B and Banerjee S: The $\mathrm{NF}-\kappa \mathrm{B}$ target genes ICAM-1 and VCAM-1 are differentially regulated during spontaneous differentiation of Caco-2 cells. FEBS J 279: 2966-2986, 2012.

19. Benzler J, Ganjam GK, Pretz D, et al: Central inhibition of $\mathrm{IKK} \beta / \mathrm{NF}-\kappa \mathrm{B}$ signaling attenuates high-fat diet-induced obesity and glucose intolerance. Diabetes 64: 2015-27, 2015.

20. Croce CM: Causes and consequences of microRNA dysregulation in cancer. Nat Rev Genet 10: 704-714, 2009.

21. Lin L, Jiang H, Huang M, et al: Depletion of histone deacetylase 1 inhibits metastatic abilities of gastric cancer cells by regulating the miR-34a/CD44 pathway. Oncol Rep: doi: 10.3892/or.2015.4010.

22. Du Y, Wang L, Wu H, et al: MicroRNA-141 inhibits migration of gastric cancer by targeting zinc finger E-box-binding homeobox 2. Mol Med Rep: doi: 10.3892/mmr.2015.3789.

23. Yu M, Gou WF, Zhao S, et al: Beclin 1 expression is an independent prognostic factor for gastric carcinomas. Tumour Biol 34: 1071-1083, 2013.

24. Lu Y, Zhu X, Liang GX, et al: Apelin-APJ induces ICAM-1, VCAM-1 and MCP-1 expression via $N F-\kappa B / J N K$ signal pathway in human umbilical vein endothelial cells. Amino Acids 43: 2125-2136, 2012.

25. Chen F, Yang D, Wang S, Che X, Wang J, Li X, Zhang Z, Chen X and Song $X$ : Livin regulates prostate cancer cell invasion by impacting the NF- $\mathrm{KB}$ signaling pathway and the expression of FN and CXCR4. IUBMB Life 64: 274-283, 2012.

26. Dutta S, Wang FQ, Wu HS, Mukherjee TJ and Fishman DA: The $\mathrm{NF}-\kappa \mathrm{B}$ pathway mediates lysophosphatidic acid (LPA)-induced VEGF signaling and cell invasion in epithelial ovarian cancer (EOC). Gynecol Oncol 123: 129-137, 2011.

27. Nourbakhsh M, Oumard A, Schwarzer M and Hauser H: NRF, a nuclear inhibitor of NF-KB proteins silencing interferon-beta promoter. Eur Cytokine Netw 11: 500-501, 2000.

28. Chen Z, Chen LY, Dai HY, Wang P, Gao S and Wang K: miR-301a promotes pancreatic cancer cell proliferation by directly inhibiting Bim expression. J Cell Biochem 113: 3229-3235, 2012. 